\title{
Surface corrosion of an Alpine karren field: recent measures at Innerbergli (Siebenhengste, Switzerland)
}

\author{
Philipp Häuselmann ${ }^{1}$
}

\begin{abstract}
:
Häuselmann Ph. 2008. Surface corrosion of an Alpine karren field: recent measures at Innerbergli (Siebenhengste, Switzerland). International Journal of Speleology, 37 (2), 107-111. Bologna (Italy). ISSN 0392-6672.

29 year old rock paintings in the Alpine karren field of Innerbergli (Siebenhengste, Switzerland) prevented the underlying rock from corrosion, while the surface nearby was corroded. Measurement of the steps indicates an average recent corrosion rate of 0.014 $( \pm 0.007) \mathrm{mm} / \mathrm{a}$. This denudation rate is very similar to those observed in other comparable places and with other means.
\end{abstract}

Keywords: recent corrosion rate, limestone denudation rate, micrometer measurement, rock paintings, Innerbergli, Siebenhengste, Switzerland.

Received 5 February 2008; Revised 22 May 2008; Accepted 29 May 2008

\section{INTRODUCTION}

Carbonate denudation measurements were done for different climatic and geomorphologic settings. Most of the time, corrosion measurements rely on either limestone tablets that corrode (Gams, 1981; Plan, 2005), or on glacially altered surfaces that corroded since the last glaciation (Bögli, 1978; Maire, 1999), or on hydrogeochemical calculations (e.g. Gunn, 1981). Only rarely in-situ micrometer measurements (e.g. High \& Hanna, 1970, Spate et al., 1985) have been published - most of the time just because of time constraints.

To enhance data availability and material for comparison, it was decided to publish this numerical contribution to recent in-situ karst denudation rates. They were made possible because of speleological work 29 years before the measurement.

\section{SITE DESCRIPTION}

The Innerbergli is one of many karrenfields within the area of Siebenhengste-Hohgant, north of Lake Thun, Switzerland (Fig. 1). Innerbergli is comparatively small, only $0.5 \mathrm{~km}^{2}$, but of exceptional beauty, not only because of its surroundings of overgrown sandstone, which makes a stark contrast with the barren limestones, but also because almost every karren form that may exist is present there - and as such it is a field laboratory for karstologists studying the surface

1 Swiss Institute of Speleology and Karst studies SISKA, c.p. 818, 2301 La Chaux-de-Fonds, Switzerland, praezis@speleo.ch morphology of karst. Such a karstification has also its expression underground - Innerbergli is one of the areas with the highest cave density of Switzerland, with 100 caves (the longest one $28 \mathrm{~km}$ ) and more than 400 small objects (to $10 \mathrm{~m}$ depth) concentrated on that small area. Caves in such a density can only be explored if there are sectors made, which then are prospected systematically. Such sectors were made in 1976 by the late Philippe Rouiller, who then in 1977 painted the sector limits directly on the rock with yellow paint. The colour being resistant to weathering, the underlying rock was no more attacked by corrosion, while the surrounding rocks continued to be eaten away by precipitation and percolation. The relief now present between the colour-covered rock and the surroundings gives a direct amount of the corrosion over the last 29 years. The limestone on which the marks were painted is called "Schrattenkalk sensu stricto" by Jeannin (1989); it is a very pure, rudist-rich member of the Lower Cretaceous Urgonian facies.

Innerbergli is situated in the first range of northern forealps, the so called Helvetic domain, at 1650 to $1920 \mathrm{~m}$ a.s.1. The climate is temperate, with an average precipitation of $1670 \mathrm{~mm}$ (Atlas of Switzerland 2.0), of which about half used to fall as snow before the presently active climate change. Snow cover was on average between mid-November to beginning May (due to the exposition of the Innerbergli to the South). The mean annual temperature averages $2.3^{\circ} \mathrm{C}$.

The ablation of the rock is necessarily from corrosion and not from erosion, because on the respective surface, there is neither stream flow of water nor 
Cavités de la région

Höhlen der Region

Caves in the area

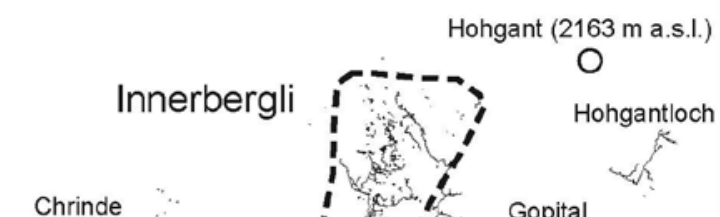

Siebenhengste - Hohgant

September 2006

0

Gemmenalphorn (2061 m a.s.I.)

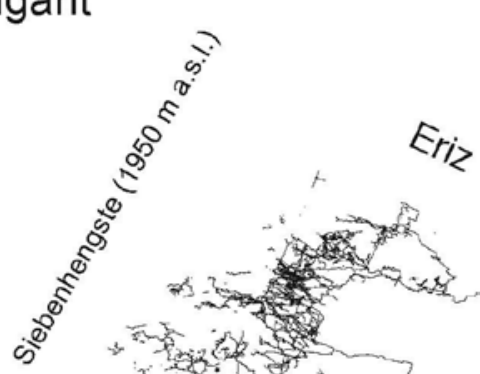

Mäanderhöhle

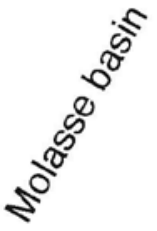

a
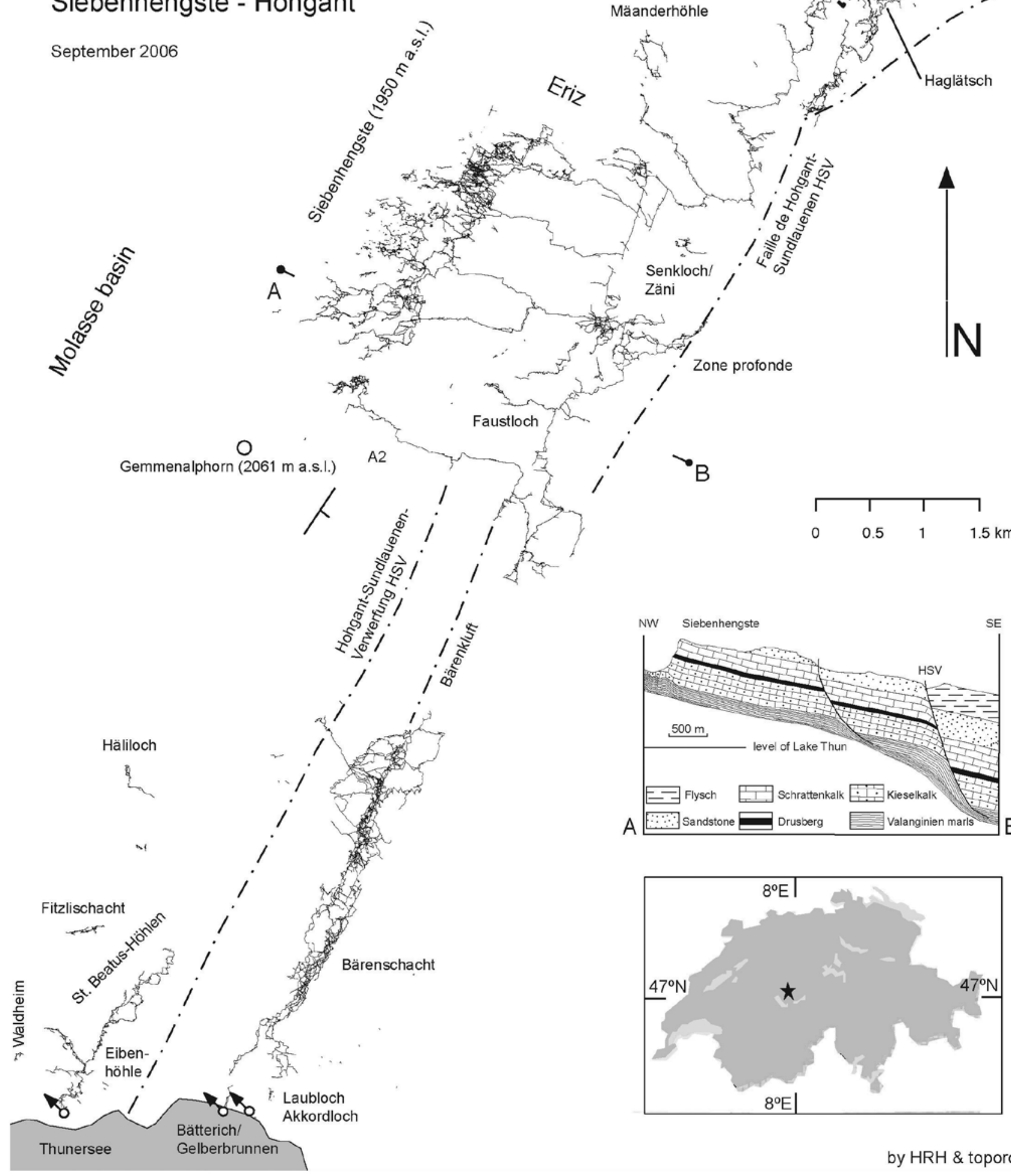

A2
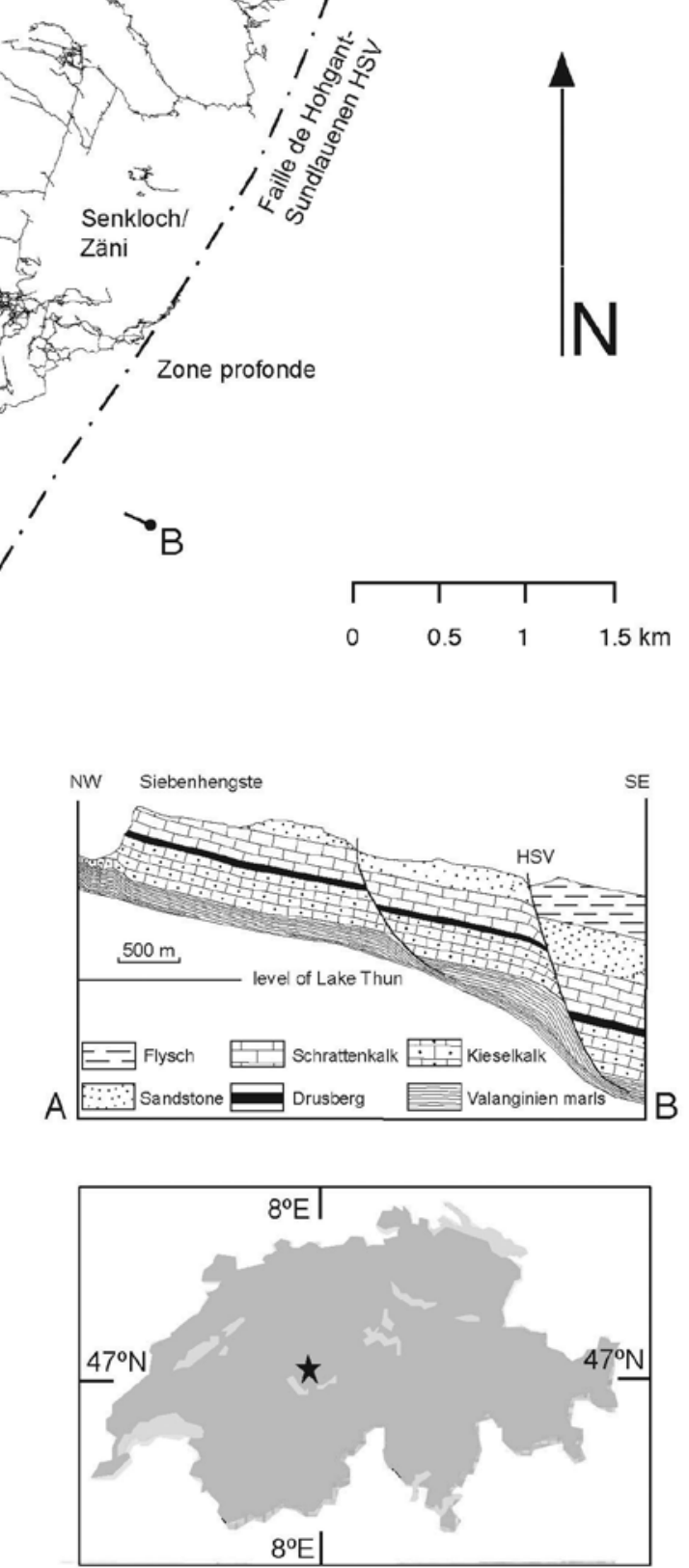

by HRH \& toporobot

Fig. 1. Overview of the cave area of the Siebenhengste. The two insets show the location within Switzerland and a tectonic cross-section. The Innerbergli site is in the North of the cave area, indicated by the dashed line. 
possibility for other eroding agents (such as large masses of gliding snow, or slope processes). This is also consistent with the preservation of the colour, which would not resist to mechanical erosion (Fig. 2).

\section{METHOD}

Relief difference was measured by a mechanical tripod micrometer (property of University of Fribourg, Switzerland). This type of micrometer is normally used on three points fixed within the rock. This is not possible in our setting here, since the micrometer has to be moved to measure first the site with colour and then the site without. This movement evidently induces errors due to the non-exact positioning of the micrometer. We tried to compensate for that by moving it only a very small distance (often $0.5 \mathrm{~mm}$ ) within places with similar relief, and by measuring the same relief at multiple points to minimize the error by statistical methods.

Thickness of paint was another issue. The elastic nature of the colour permitted to take it off the rock in some rare places, so that the rock thickness before and after removal could be measured (Fig. 3). In addition, the colour chips obtained were measured in the field by the micrometer. Statistical calculations revealed that the colour thickness was $0.149 \mathrm{~mm}( \pm$ $0.030 \mathrm{~mm}$ ). In the following calculations, only the limestone values without colour were used.

\section{RESULTS}

The obtained results vary quite a bit, from $0.254 \mathrm{~mm}$ to $0.556 \mathrm{~mm}$ total corrosion (see Table 1 and Fig. 4), which makes 0.0088 to $0.0192 \mathrm{~mm}$ per year. This variation could be due to exposition of the limestone surface (horizontal, inclined, or vertical) and to the presence or absence of vegetation in the immediate vicinity of the paintings. However, this explanation is not sufficient, because the lowermost value was found on a horizontal surface with no vegetation nearby, whereas another place with the second-highest corrosion had exactly the same disposition. We think that microclimate, thus the amount of available water, and the exposition, are the main factors for the differences.

The overall average for the Innerbergli is $0.014 \pm$ $0.007 \mathrm{~mm}$ of corrosion per year.

\section{DISCUSSION}

A comparison with literature should indicate whether the above results correspond, in the order of magnitude, to other measured values. It is very difficult to get meaningful comparisons, because many measurements were done by means other than micrometers, and thus they represent averages over longer time periods, or total ablation including areas covered by soil (in the case of hydrogeochemical measurements). A non-complete overview of data is presented in Table 2 .

Bögli (1971) calculated the karst denudation in Muotatal (Switzerland) by hydrochemical means. He stated that in the bare karren field, $0.071 \mathrm{~mm} / \mathrm{a}$ are denuded, of which $0.014 \mathrm{~mm} / \mathrm{a}$ should occur at the

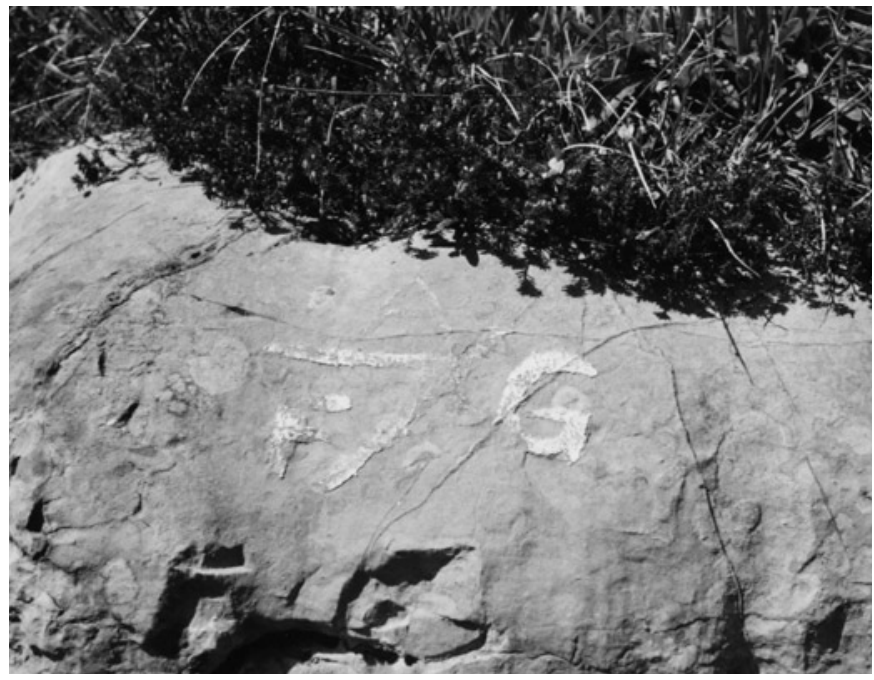

Fig. 2. One of the painted letters indicating caving sectors. Approximate size of letter $\mathrm{G}$ is $7 \mathrm{~cm}$.

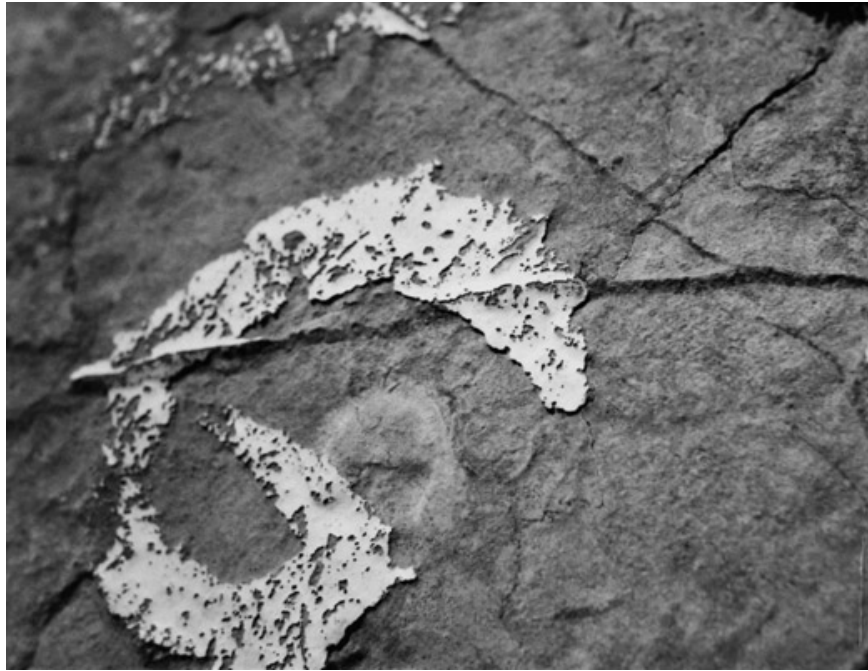

Fig. 3. Close-up photograph of the paintings. The downweathering of the bare limestone surface is easily visible. Approximate size of letter $G$ is $7 \mathrm{~cm}$.

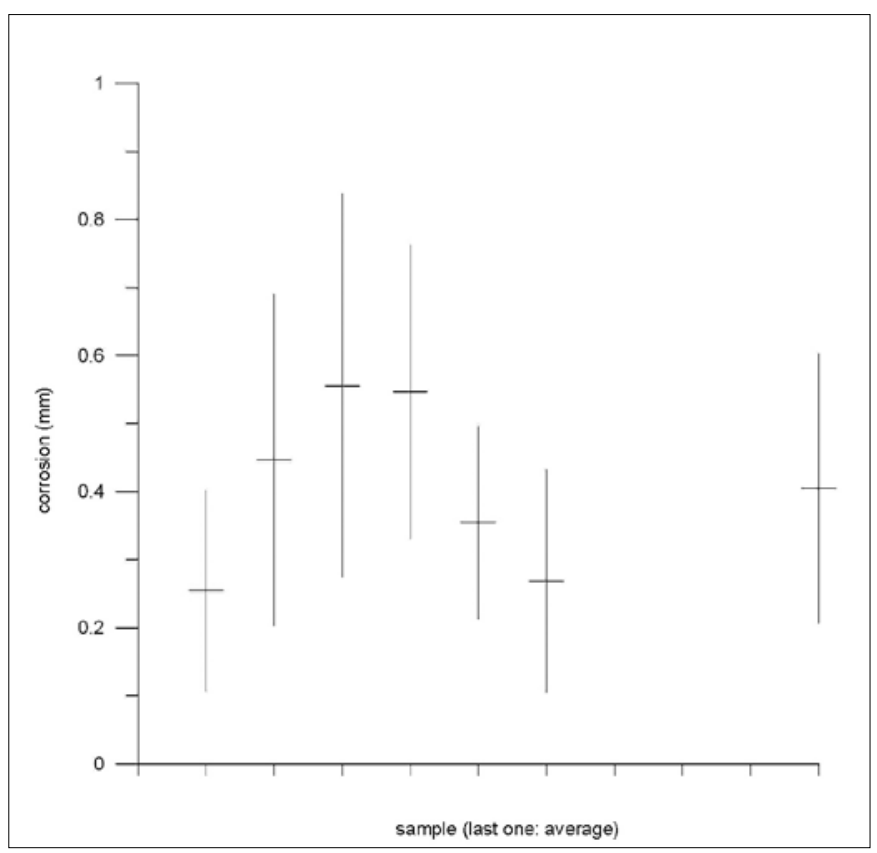

Fig. 4. Graph of the average downweathering for the last 29 years. The overall average value for all measured sites is shown at the right. As also seen in Table 1, the range of values is quite high. 


\begin{tabular}{|c|c|c|c|c|c|c|}
\hline \multirow[t]{2}{*}{ Measured point } & \multicolumn{3}{|c|}{ Coordinates (Swiss grid) } & \multirow{2}{*}{$\begin{array}{c}\text { Number of } \\
\text { measurements }\end{array}$} & \multirow{2}{*}{$\begin{array}{c}\text { Results } \\
(\mathrm{mm})\end{array}$} & \multirow{2}{*}{$\begin{array}{c}\text { Deviation } \\
(\mathrm{mm})\end{array}$} \\
\hline & $\mathbf{x}$ & $y$ & $\mathbf{z}$ & & & \\
\hline D-L-200 & 633692 & 181227 & 1762 & 6 & 0.255 & 0.147 \\
\hline G-D-H-200 & 633633 & 181316 & 1773 & 11 & 0.447 & 0.243 \\
\hline A-F-G & 633396 & 181327 & 1794 & 13 & 0.556 & 0.281 \\
\hline I-J-200 & 633593 & 181563 & 1850 & 10 & 0.547 & 0.215 \\
\hline A-E-F & 633431 & 181164 & 1769 & 10 & 0.355 & 0.141 \\
\hline D-F-G & 633626 & 181259 & 1784 & 11 & 0.269 & 0.163 \\
\hline Paint thickness & & & & 5 & 0.149 & 0.030 \\
\hline Average value & & & & 61 & 0.405 & 0.198 \\
\hline Average per year & & & & 61 & 0.014 & 0.007 \\
\hline
\end{tabular}

Table 1. Measured values and their deviation. The values are net corrosion; the colour thickness is subtracted

\begin{tabular}{|c|c|c|c|c|c|c|c|}
\hline $\begin{array}{l}\text { Measured } \\
\text { point }\end{array}$ & Site & karst type & $\begin{array}{l}\text { altitude } \\
\text { (m a.s.I.) }\end{array}$ & $\begin{array}{l}\text { annual rainfall } \\
(\mathrm{mm})\end{array}$ & method used & $\begin{array}{l}\text { rate } \\
(\mathrm{mm} / \mathrm{a})\end{array}$ & source \\
\hline \multirow[t]{5}{*}{ arctic } & Spitsbergen, Norway & bare karst & & & vein protruding & 0 & Akerman (1983) \\
\hline & Svalbard, Norway & bare karst & & & hydrochemistry & $0.004-0.035$ & Krawczyk (2008) \\
\hline & Svartisen, Norway & bare karst & 200 & 2600 & hydrochemistry & 0.03 & Lauritzen (1990) \\
\hline & Alaska & bare karst & & $1750-2540$ & micrometer & 0.04 & Allred (2004) \\
\hline & Alaska & forested karst & & $1750-2540$ & micrometer & 0.03 & Allred (2004) \\
\hline \multirow[t]{9}{*}{ alpine } & Silberen, Switzerland & bare karst & 2200 & 2400 & hydrochemistry & 0.01 & Bögli (1971) \\
\hline & Bödmeren, Switzerland & forested karst & 1300 & 2100 & hydrochemistry & 0.08 & Bögli (1971) \\
\hline & Innerbergli, Switzerland & bare karst & 1800 & 1670 & micrometer & 0.01 & Häuselmann, this volume \\
\hline & Kanin, Italy & bare karst & 2000 & 2800 & micrometer & $0.01-0.035$ & Forti (1984) \\
\hline & Kanin, Slovenia & bare karst & 2200 & 3500 & micrometer & $0.017-0.1$ & Kunaver (1979) \\
\hline & Steinernes Meer, Austria & bare karst & 2000 & 2200 & micrometer & 0.03 & Pavuza (unpublished) \\
\hline & Hochschwab, Austria & bare karst & 2000 & 2150 & carbonate tablet & 0.01 & Plan (2005) \\
\hline & Hochschwab, Austria & covered karst & 2000 & 2150 & carbonate tablet & $0.013-0.04$ & Plan (2005) \\
\hline & Vercors, France & covered karst & 1060 & 1640 & carbonate tablet & 0.02 & Gams (1985) \\
\hline \multirow[t]{4}{*}{ mediterranean } & Classical karst, Italy & covered karst & 300 & 1440 & micrometer & $0.01-0.041$ & Forti (1984) \\
\hline & Classical karst, Italy & bare karst & 300 & 1350 & micrometer & 0.03 & Cucchi et al. (1987) \\
\hline & Classical karst, Italy & bare karst & 300 & 1350 & micrometer & 0.02 & Cucchi et al. (1995) \\
\hline & NSW, Australia & & & 950 & micrometer & $0.0-0.02$ & Spate et al. (1985) \\
\hline \multirow[t]{2}{*}{ tropic } & Patagonia, Chile & bare karst & 200 & 7300 & vein protruding & 0.06 & Maire (1999) \\
\hline & Puerto Rico & covered karst & 323 & 1690 & carbonate tablet & 0.01 & Gams (1985) \\
\hline mixed areas & Friuli-Venezia, Italy & mixed & mixed & mixed & micrometer & $0.01-0.04$ & Cucchi et al. (1994) \\
\hline
\end{tabular}

Table 2. Table of different values found in literature. The values are in general quite comparable to ours.

surface, and $0.057 \mathrm{~mm} / \mathrm{a}$ underground. The altitude of measurement at Bögli (1971) is slightly higher, as is the precipitation $(2400 \mathrm{~mm} / \mathrm{a})$. However, his determined value is exactly ours. Bögli further stated that covered karst resulted not only in higher denudation rate, but also in much higher surface removal (as opposed to corrosion within the caves beneath). Unfortunately, we do not have measurements of forested karst areas.

An overview of karst denudation rates presented in Bögli (1978) gives rates that vary from 0.017 (Spitsbergen) to $0.091 \mathrm{~mm} / \mathrm{a}$ (forested karst Muotatal). These values are calculated for total denudation, of which 20 (bare karst) to $90 \%$ (covered karst) should occur at the surface. Most of the values presented in Bögli, however, are within areas where covered karst predominates, so these values cannot be compared to ours.

Cucchi \& Forti (1994, after Ford \& Williams, 2007) measured, with the help of a micrometer, more than
50 sites in northern Italy, and got an average surface lowering rate of $0.02 \mathrm{~mm} / \mathrm{a}$, so quite comparable to ours. Spate et al. (1985) measured limestone surfaces in Australia and got an average value of $0.007 \pm 0.011 \mathrm{~mm} / \mathrm{a}$. This value is half the one of Innerbergli, but the precipitation on that Australian site is also about half. On the contrast, Allred (2004) found 0.03 to $0.04 \mathrm{~mm} / \mathrm{a}$ in rainy parts $(1800-2500$ $\mathrm{mm} / \mathrm{a})$ of Alaska. These values are significantly higher than ours even if taking into account the effect of rainfall.

In general, the measured values at Innerbergli are in the same magnitude as other measurements. Although more difficult to measure because of the conditions (non-fixed micrometer), they represent average values for the last 29 years and may therefore be of interest to the scientific community.

The average value of corrosion at Innerbergli, $0.014 \mathrm{~mm} / \mathrm{a}$, equals $1.2 \times 10^{-9} \mathrm{moles} / \mathrm{m}^{2} \mathrm{x} \mathrm{sec}$. 
This value is 100 to 1000 times smaller than the one given by Kaufmann \& Dreybrodt (2007). However, their value is for rapid corrosion during rainfall, whereas our value is averaged over the whole year (with and without rainfall). To allow a direct comparison, we would have to know how many seconds per year it is raining at Innerbergli. Alternatively, taking above numbers, we could also conclude that the season without flowing water is 100 to 1000 times longer than the one with flowing water. The findings of Kaufmann \& Dreybrodt (2007), however, are very important and might actually explain why a plot of total rainfall and corrosion rate (as it was tried on the base of Table 2) does not yield a straight line: if the time during which rain is falling is more important than the actual rainwater quantity, then regions with few constant rain (Alaska, Ireland) would have potentially higher corrosion rates than areas with rare torrential rains. This would be an interesting point to investigate in the future.

\section{ACKNOWLEDGEMENTS}

The University of Fribourg Switzerland (M. Monbaron) is thanked for permission to use the micrometers. A review of Jo De Waele, Lukas Plan and Stein-Erik Lauritzen improved the manuscript. Jo De Waele helped additionally with literature that was difficult to find.

\section{REFERENCES}

Akerman J.H., 1983 - Notes on chemical weathering, Kapp Linne, Spitzbergen. Proceedings $4^{\text {th }}$ International Conference on Permafrost, National Academy Press, Washington DC, 10-15.

Allred K., 2004 - Some carbonate erosion rates of southeast Alaska. Journal of Cave and Karst Studies, 66(3): 89-97.

Bögli A., 1971 - Karstdenudation - das Ausmass des korrosiven Kalkabtrages. Regio Basiliensis, 12(2): 352361.

Bögli A., 1978 - Karsthydrographie und physische Speläologie. Springer Verlag, Berlin: 292 p.

Cucchi F., Forti F. \& Finocchiaro F., 1987 - Carbonate surface solution in the classical karst. International Journal of Speleology 16: 125-138.

Cucchi F., Forti F. \& Ulcigrai F., 1994 - Degradation by dissolution of carbonate rocks. Acta Carsologica, 23: 55-62.
Cucchi F., Forti F. \& Marinetti E., 1995 - Surface degradation in the carbonate rocks of the karst of Trieste. In Fornos J.J. \& Ginès A. (Eds.), Karren landforms, Proceedings of the international symposium on karren landforms: 41-51.

Ford D.C. \& Williams P., 2007 - Karst hydrogeology and geomorphology. Wiley, Chichester, UK, 562 p.

Forti F., 1984 - Messungen des Karstabtrages in der Region Friul-Julisch-Venetien (Italien). Die Höhle 35 (3/4): 135139.

Gams I., 1981 - Comparative research of limestone solution by means of standard tablets. 8th Int. Congress of Speleology, Huntsville, USA: 273-275.

Gams I, 1985 - International comparative measurements of surface solution by means of standard limestone tablets. Zbornik Ivana Rakovca XXVI: 361-386.

Gunn J., 1981 - Limestone solution rates and processes in the Waitomo district, New Zealand. Earth Surface Processes and Landforms, 6: 427-445.

High C. \& Hanna G.K., 1970 - A method for the direct measurement of erosion of rock surfaces. British Geomorphological Research Group Technical Bulletin, 5: $24 \mathrm{p}$.

Jeannin P.-Y., 1989 - Etude géologique de la région BurstSieben Hengste. Unpublished Diploma thesis, University of Neuchâtel, $121 \mathrm{p}$.

Kaufmann G. \& Dreybrodt W., 2007 - Calcite dissolution kinetics in the system $\mathrm{CaCO}_{3}-\mathrm{H}_{2} \mathrm{O}-\mathrm{CO}_{2}$ at high undersaturation. Geochimica et Cosmochimica Acta, 71 (6): 1398-1410.

Kunaver J., 1979 - Some experiences in measuring the surface karst denudation in high alpine environment. Actes du Symposium international sur l'érosion karstique, Aix en Provence 1979, 75-85.

Krawczyk W.E., 2008 - The range of chemical denudation rates on Svalbard. - Geophysical Research Abstracts 10, EGU General Assembly 2008.

Lauritzen S.E., 1990 - Autogenic and allogenic denudation in carbonate karst by the multiple basin method: An example from Svartisen, North Norway. Earth Surface Processes and Landforms, 15: 157-169.

Maire R., 1999 - Les glaciers de marbre de Patagonie, Chili. Karstologia, 33: 25-40.

Plan L., 2005 - Factors controlling carbonate dissolution rates quantified in a field test in the Austrian Alps. Geomorphology, 68: 201-212.

Spate A.P, Jennings J.N., Smith D.I. \& Greenaway M.A., 1985 - The micro-erosion meter: use and limitations. Earth Surface Processes and Landforms, 10: 427-440. 